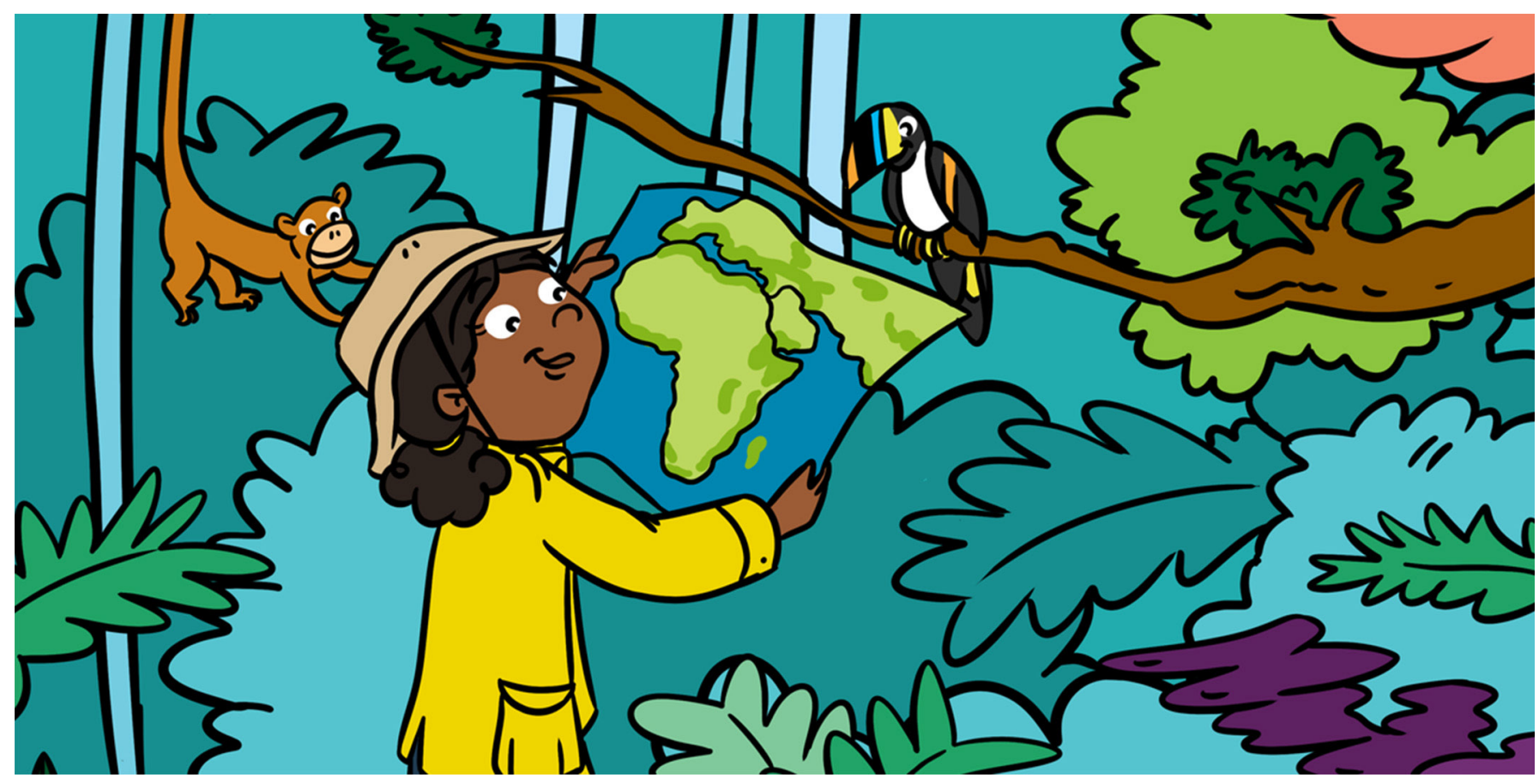

\title{
WHAT ARE BIODIVERSITY HOTSPOTS?
}

\section{Melanie Merritt ${ }^{1}$, Maria Eduarda Maldaner ${ }^{2}$ and Ana Maria Rocha de Almeida ${ }^{1 *}$}

${ }^{1}$ Department of Biological Sciences, California State University East Bay, Hayward, CA, United States

${ }^{2}$ Laboratório de Scarabaeoidologia, Instituto de Biociências, Universidade Federal de Mato Grosso, Cuiabá, Brazil

\section{YOUNG REVIEWERS:}

SONGO.INFO

AGES: $10-16$
The image of a tropical forest is likely present in your imagination: green, warm, and wet, with large trees, thick shrubs, and a wide variety of insects, birds, and mammals. This image is accurate: the tropical zone has an incredible abundance of species of plants and animals. Species in tropical regions can account for two-thirds of all known species on earth! Many areas within the tropical zones are considered biodiversity hotspots and are home to the world's most rare and endangered species. Whether we are talking about mountain ranges, islands, or tropical forests, the impressive diversity of life in these areas makes them important places to protect and study. In this article we will discuss the concept of biodiversity hotspots, their locations throughout the planet, and their importance for biodiversity conservation.

\section{HOW MANY SPECIES ARE THERE?}

Have you ever wondered just how many different species of living things there are on our planet? This is a hard question to answer! 
CONSERVATION

Taking care and preserving species and the environment.

\section{SPECIES RICHNESS}

The number of species living in a specific location.

TROPICAL AREA OR TROPICAL ZONE

Area situated between the Tropics of Cancer and Capricorn. See Figure 1 for the location of the location of the Tropics on the globe.

\section{EXTINCTION}

The death of an entire species (like dinosaurs)
The actual number of living organisms on Earth is unknown to us, but so far, scientists have described up to 1.7 million species of living organisms. Of those, over 1.3 million are animals, 100,000 are fungi, over 300,000 are plants, plus countless species of bacteria, algae, and viruses [1]. This incredible variety of life forms is what we know as biodiversity, that is, all kinds of life existing in a certain place.

It is difficult to know the actual number of living organisms on Earth, or what percentage of these organisms are already known to us. In some cases, there is quite a lot of debate. For example, the estimated number of animals varies from 2 to 11 million species. And while the average estimate of known plant species is somewhere around 300,000, the predicted number of plants, including yet unknown species, is around 450,000 species [1]. In any case, scientists agree that, despite the great number of species that have already been discovered, it is likely that there is an even larger number of species yet to be discovered.

Now you might wonder, "Okay, that is nice to know, but what difference does it make?" It makes all the difference! When we are trying to protect the biodiversity on our planet, knowing how many species are out there is as important as knowing how and where they are distributed around the globe, so that we can decide which areas of the planet are priorities for conservation, especially if we cannot protect every area.

\section{BIODIVERSITY IS UNEVENLY DISTRIBUTED AROUND THE GLOBE}

With the enormous number of species that exists on Earth, it is remarkable that the distribution of these species is so highly concentrated in specific areas. Species richness, the total number of species found in an area, is not evenly distributed around the globe: two-thirds of all known species occur in tropical areas, especially in tropical forests [2], even though the causes of such uneven distribution are still a matter of debate.

In order to prioritize the areas that should be protected, scientists look for areas that are home to a large number of species, especially those species that are under threat of extinction or that are currently being destroyed at a fast pace. These areas that are particularly important for biodiversity conservation are called biodiversity hotspots. Two things are crucial when determining that a place is a biodiversity hotspot: (i) the number of different species there; and (ii) whether species in that area are endangered or currently being destroyed. Figure 1 shows the location of 36 biodiversity hotspots, according to the Critical Ecosystem Partnership Fund. 
Figure 1

The names and locations of current biodiversity hotspots around the globe [9].

\section{BIODIVERSITY HOTSPOTS}

Geographical areas with very large numbers of species that are threatened by destruction.

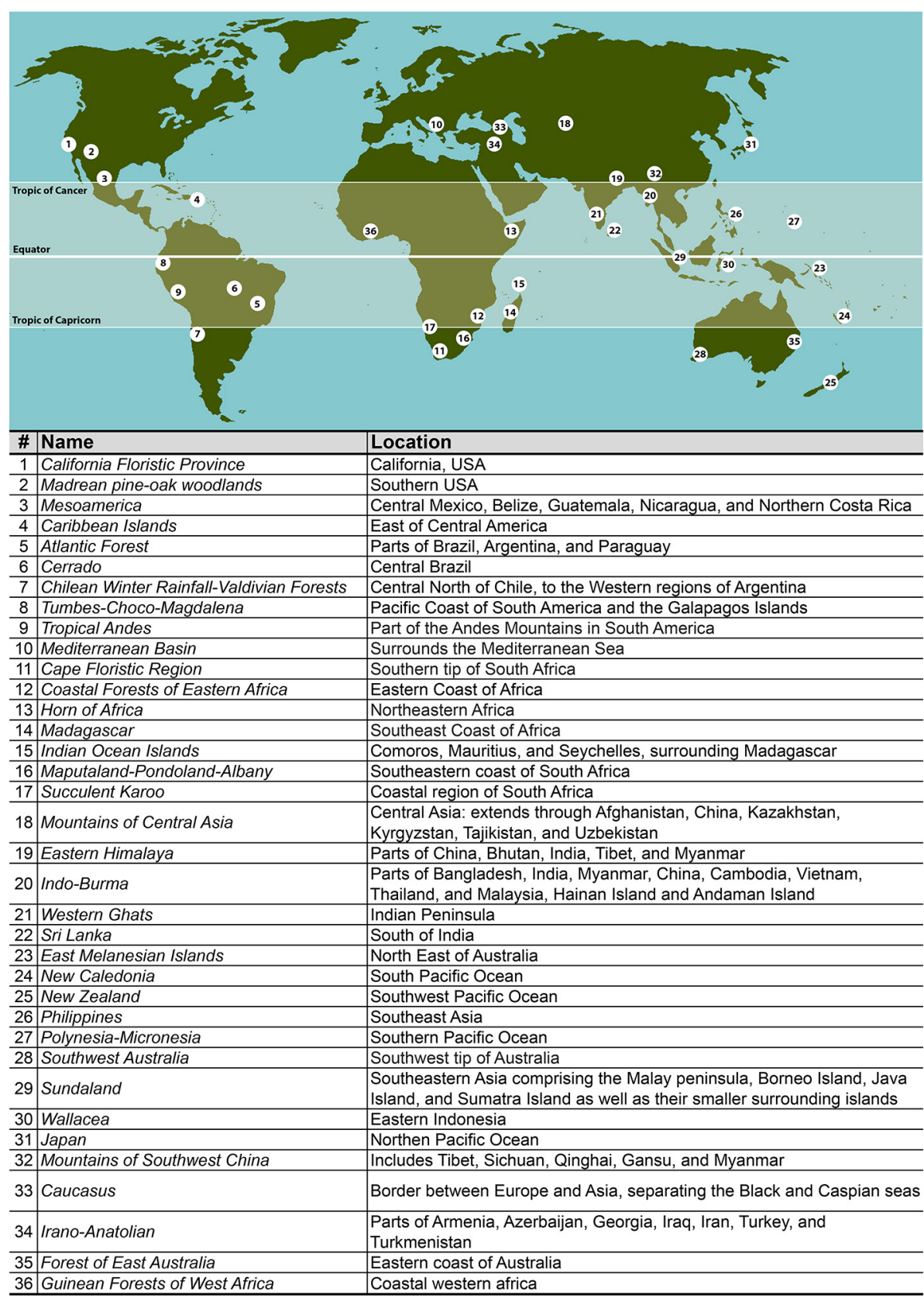

Scientists have observed that, even though biodiversity hotspots make up only approximately $1.4 \%$ of land on our planet, they are home to $60 \%$ of Earth's plant, bird, mammal, and reptile species [3]. Just the endangered species in the tropics account for $43 \%$ of vertebrates (animals with backbones and its close relatives) and $80 \%$ of all amphibians [4]. Species that found only in a certain geographical area are known as endemic species, and biodiversity hotspots are full of them! For example, the Banana Tree Frog can only be found in Ethiopia, and you will only find lemurs in Madagascar [5]. Tropical forests are typically biodiversity hotspots and are usually filled with endemic species. The Upper Amazonia/Guyana Shield, the Congo Basin, and 
Figure 2

Biodiversity hotspots and some of their endemic species.

(a) Melanesian Islands;

(b) Emerald Lakes,

New Zealand;

(c) Diademed sifaca, one of the endemic lemur species from Madagascar. Mantadia National Park,

Madagascar; (d) Maned wolf, the largest canid

of South America,

a species from the

Cerrado hotspot;

(e) Atlantic Forest,

Caparaó, Brazil:

(f) Rafflesia, one of

the largest flowers in

nature. This particular

one, from Borneo, is 80

$\mathrm{cm}$ wide [Photo (a): Jim

Lounsbury, Wikipedia

(https://commons.

wikimedia.org/w/index php? curid=9403460;

Photo (b): Marcus

Holland-Moritz,

Wikipedia (https://

commons.wikimedia.

org/w/index.

php? curid =40728121);

Photo (c): C. Michael

Hogan, Wikipedia

(https://commons.

wikimedia.org/wiki/

File:Diademed_ready_

to_push_off.jpg); Photo

(d): Aguara, Wikipedia

(https://pt.wikipedia.

org/wiki/Lobo-guar\%

C3\%A1\#/media/

File:Aguara1.jpg); Photo

(e): Heris Luiz Cordeiro

Rocha, Wikipedia (https://

commons.wikimedia.

org/wiki/File:Capara\%

C3\%B3_e_a_Mata_Atl\%

C3\%A2ntica.jpg); Photo

(f): Steve Cornish,

Wikipedia (https://en.wi

kipedia.org/wiki/

Rafflesia\#/media/File:

Rafflesia_80_cm.jpg)].

\section{CLIMATE CHANGE}

The change of weather and temperature patterns around the world.

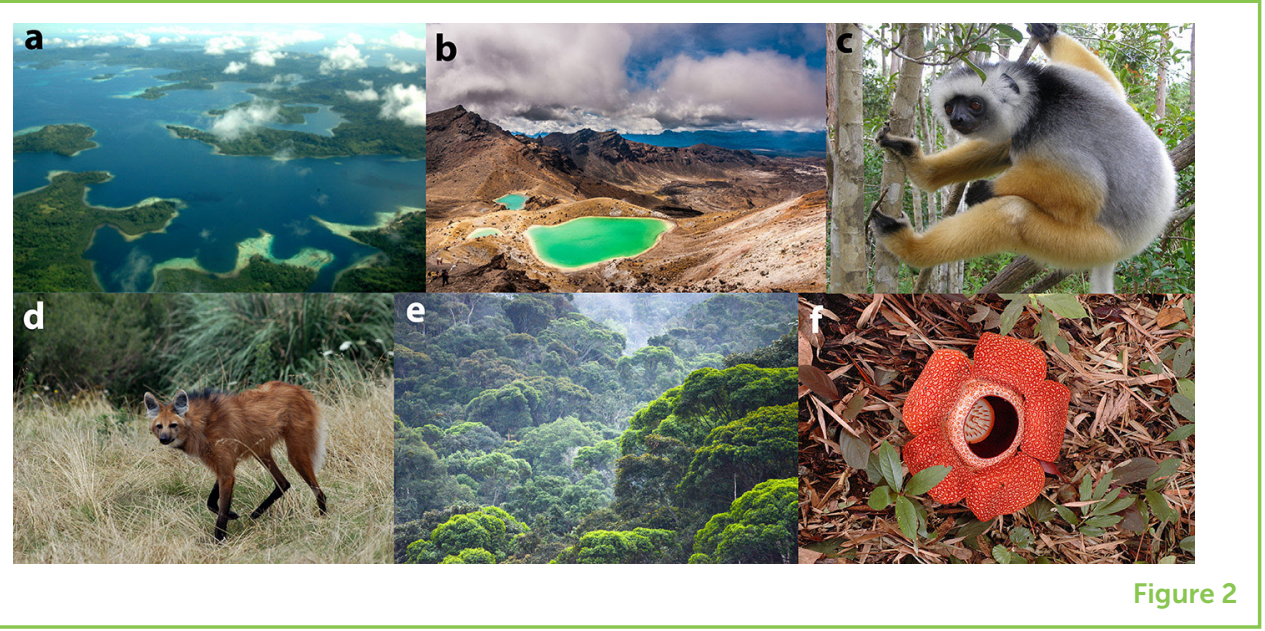

the New Guinea/Melanesian Islands have the highest number of endemic terrestrial (land-living) species on Earth [6]. Figure 2 shows some examples of biodiversity hotspots and some of their endemic animals and plants.

In addition to land, the waters surrounding these tropical regions are just as important, and equally in danger [4]. Tropical coral reefs are currently being threatened by climate change and habitat destruction. These areas are some of the most biodiverse ecosystems on our planet! Scientific studies of 3,235 marine species in these areas, including fishes, corals, snails, and lobsters, show that high percentages of these species are at serious risk of becoming extinct [7]. Conservation of species living in fresh or seawater is especially difficult, because many bodies of water are interconnected. For example, all the oceans are connected through sea currents that allow the movement of species, minerals, and pollution across the entire globe [8].

\section{EXTINCTIONS AND A LOOK INTO THE FUTURE}

Interestingly, the organisms that we know today represent only a very small portion of all the living creatures that have inhabited the planet since life began. All the species living today represent only $5 \%$ of all the species that have roamed the Earth during its history! This is a reminder that extinction is a constant force shaping Earth's biodiversity.

However, many scientists would agree that, today, we are facing a rate of species extinction that is faster than has ever been seen before. Plant and animal species in biodiversity hotspots are currently suffering devastating losses. In fact, by definition, a biodiversity hotspot must have lost at least $70 \%$ of its habitat [9]. Biodiversity hotspots now cover only $1.4 \%$ of the land on Earth, when they originally covered $12 \%$ of the land [10]. Factors, such as pollution, exploitation of land, invasive 


\section{DEFORESTATION}

The destruction of forests or the removal of great number of trees. species, deforestation, and climate change are the leading causes of habitat loss and destruction [11]. The fact that these factors are widespread creates challenges for the species that manage to survive; and with an ever-changing climate and unpredictable circumstances, species that cannot resist the changing environment or move to a more suitable habitat will likely become extinct [4].

When we think about the future of biodiversity on Earth, we need to consider the role we play in climate change. Some scientists predict that up to $54 \%$ of species are at risk of extinction due to climate change. The consequences of climate change are extremely widespread, threatening even places untouched by humans [12]. In order to protect our planet, we can start by making small changes in our daily lives. Taking action by recycling, picking up trash, being conservative with our water consumption, and limiting pollution by walking, biking, or taking public transportation are ways that we can help the environment. We can also come up with our own ideas, as we educate ourselves on biodiversity by reading about different places and living things.

\section{SUMMARY}

As we have learned, a region with a large number of species is considered to be biodiverse. There are 36 biodiversity hotspots on our planet, and these areas are dazzling, unique, and full of life. Plants, animals, and other living organisms that populate these places are rare and many of them are only found in these specific geographic areas. These biodiversity hotspots are currently at risk of being destroyed [13]. Habitat destruction directly caused by humans, as well as destruction due to climate change, are the leading causes of the increasing extinction of Earth's species.

\section{ACKNOWLEDGMENTS}

AA would like to thank INCT (IN-TREE, 465767/2014-1) for support.

\section{REFERENCES}

1. Monastersky, R. 2014. Biodiversity: life - a status report. Nature 516:158-61. doi: $10.1038 / 516158 a$

2. Pimm, S. L., and Raven, P. 2000. Extinction by numbers. Nature 403:843-5. doi: $10.1038 / 35002708$

3. Possingham, H. P., and Wilson, K. A. 2005. Biodiversity: turning up the heat on hotspots. Nature 436:919-20. doi: 10.1038/436919a 
4. Marchese, C. 2015. Biodiversity hotspots: a shortcut for a more complicated concept. Glob. Ecol. Conserv. 3:297-309. doi: 10.1016/j.gecco.2014.12.008

5. Herrera, J. P. 2017. Testing the adaptive radiation hypothesis for the Lemurs of Madagascar. R. Soc. Open Sci. 4:161014. doi: 10.1098/rsos.161014

6. Cincotta, R. P., Wisnewski, J., and Engelman, R. 2000. Human population in the biodiversity hotspots. Nature 404:990-2. doi: 10.1038/35010105

7. Roberts, C. M., McClean, C. J., Veron, J. E., Hawkins, J. P., Allen, G. R., McAllister, D. E., et al. 2002. Marine biodiversity hotspots and conservation priorities for tropical reefs. Science 295:1280-4. doi: 10.1126/science.1067728

8. Pimm, S. L., Jenkins, C. N., Abell, R., Brooks, T. M., Gittleman, J. L., Joppa, L. N., et al. 2014. The biodiversity of species and their rates of extinction, distribution, and protection. Science 344:1246752. doi: 10.1126/science.1246752

9. CEPF. 2018. Critical Ecosystem Partnership Fund. Available online at: https://www. cepf.net/ (last accessed April 16, 2018).

10. Brooks, T. M., Mittermeier, R. A., Mittermeier, C. G., Da Fonseca, G. A., Rylands, A. B., Konstant, W. R., et al. 2002. Habitat loss and extinction in the hotspots of biodiversity. Conserv. Biol. 16:909-23. doi: 10.1046/j.1523-1739.2002.00530.x

11. Barnosky, A. D., Hadly, E. A., Bascompte, J., Berlow, E. L., Brown, J. H., Fortelius, M., et al. 2012. Approaching a state shift in Earth's biosphere. Nature 486:52-8. doi: $10.1038 /$ nature11018

12. Malcolm, J. R., Liu, C., Neilson, R. P., Hansen, L., and Hannah, L. 2006. Global warming and extinctions of endemic species from biodiversity hotspots. Conserv. Biol. 20:538-48. doi: 10.1111/j.1523-1739.2006.00364.x

13. Myers, N., Mittermeier, R. A., Mittermeier, C. G., Da Fonseca, G. A., and Kent, J. 2000. Biodiversity hotspots for conservation priorities. Nature 403:853-8. doi: $10.1038 / 35002501$

SUBMITTED: 25 June 2018; ACCEPTED: 07 February 2019;

PUBLISHED ONLINE: 07 March 2019

EDITED BY: Sophie von der Heyden, Stellenbosch University, South Africa

CITATION: Merritt M, Maldaner ME and de Almeida AMR (2019) What Are Biodiversity Hotspots? Front. Young Minds 7:29. doi: 10.3389/frym.2019.00029

CONFLICT OF INTEREST STATEMENT: The authors declare that the research was conducted in the absence of any commercial or financial relationships that could be construed as a potential conflict of interest.

COPYRIGHT @ 2019 Merritt, Maldaner and de Almeida. This is an open-access article distributed under the terms of the Creative Commons Attribution License (CC BY). The use, distribution or reproduction in other forums is permitted, provided the original author(s) and the copyright owner(s) are credited and that the original publication in this journal is cited, in accordance with accepted academic practice. No use, distribution or reproduction is permitted which does not comply with these terms. 


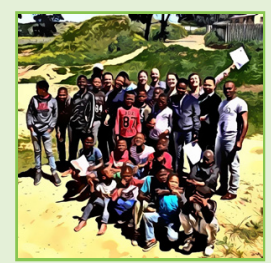

\section{YOUNG REVIEWERS}

\section{SONGO.INFO, AGES: 10-16}

We are the kids of a vibrant township community in South Africa. Where we live, education is difficult for many people, and we strive to improve our lives through sports and learning. We are all different ages, and after school we enjoy practicing our cycling skills. We also compete in cycling events locally and nationally. We believe that education is important, and will help us grow in the future.

\section{AUTHORS}

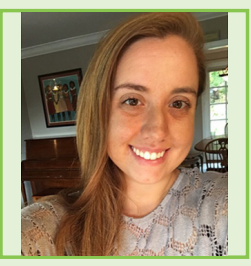

\section{MELANIE MERRITT}

I am a senior at CSU East Bay, hopefully earning my Bachelor of Science in Biology this spring. My interests include plant biology, genetics, and the effects that climate change has on different organisms. I hope to begin a Ph.D. program in Plant Biology in the fall and I am excited to continue doing research.

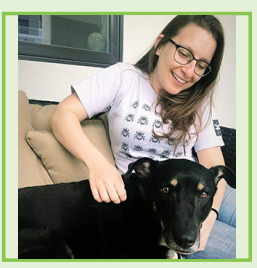

\section{MARIA EDUARDA MALDANER}

I am a Biologist that still asks "why? how? what if...?" I am fascinated by all aspects of nature, especially how evolution works. Also, I am very interested in how biological diversity is distributed around the world. I work with dung beetles and they are the coolest insects! My work includes the description of new species and the study of closely related groups.

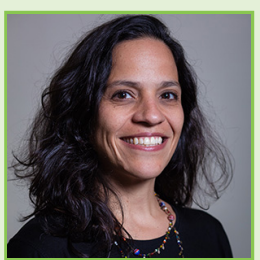

\section{ANA MARIA ROCHA DE ALMEIDA}

I am a Biologist and a Medical Doctor who loves to study the genetic and molecular aspects of development and evolution. I earned my Ph.D. from UC Berkeley working on flower development and evolution of gingers. I continue to do research in plant development and evolution at Cal State East Bay (CSUEB), where I also teach many classes in related topics. I am fascinated by nature's beauty, especially by the innumerous forms we see in the living world. *ana.almeida@csueastbay.edu 